\title{
Notes on the Swimming Methods and Habits of Certain Crustacean Larvæ.
}

\author{
By
}

\author{
G. E. H. Foxon, M.A.,
}

From the Department of Zoology, University of Glasgow, and the Marine Station, Millport.

With 7 Figures in the Text.

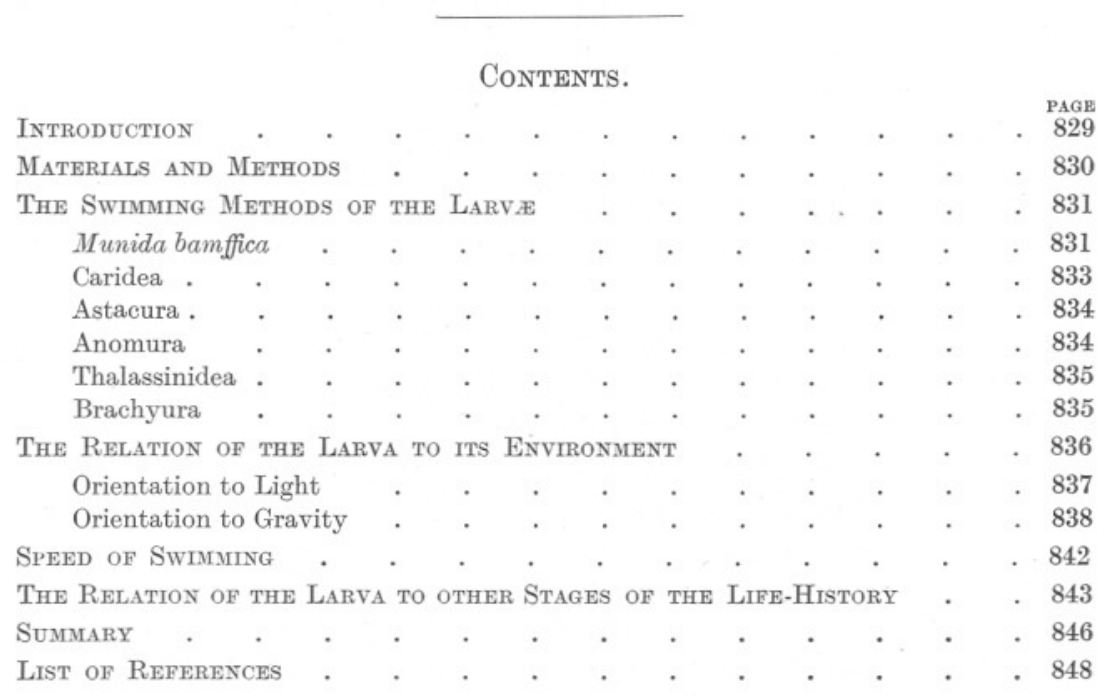

INTRODUCTION.

UNTIL recently most work on larval Decapoda and Euphausiacea had been concerned with the elucidation of the life-histories of various species ; latterly, since our knowledge of some of the commoner species has become more complete, other work has been undertaken. For example, Russell and others have clearly demonstrated the existence of diurnal migrations which these larvæ make in the sea, and we now know the extent of the migrations of various species. Other workers have experimented in the laboratory to find the cause or causes of the migrations. Little attention, however, seems to have been paid to the methods by which the migrations are accomplished; such remarks as have been made on the swimming powers and habits of these larvæ are to be found in works mainly devoted to other aspects of the problem. An attempt has been made to bring together some of these remarks and to supplement 
them with fresh observations on some of the more easily obtainable larvæ.

It must be made clear from the outset that plankton problems are not the only ones connected with the swimming habits of crustacean larvæ. The young crustacean being a free-living larva well adapted to its environment it follows that as swimming is the most important function at this stage of the life-history many of the morphological peculiarities of the larvæ are correlated with it. It has, therefore, been thought advisable to inquire into the closeness of the relationship between the swimming habits and the larval structure. Such a consideration appears to throw a certain amount of light on the functional significance of the abrupt changes of form met with during the life-histories of certain species.

It must be admitted that these two problems, one entirely physiological, the other bearing on points of Morphology and Phylogeny, are not necessarily closely related; but as the observations here recorded appear to merit discussion from both points of view it is convenient to bring these somewhat dissimilar subjects together rather than to deal with them separately.

I have to record my best thanks to the director of the Marine Station, Millport, for the facilities placed at my disposal during my visits to the station and for the regular supplies of plankton received at Glasgow. Also to Dr. W. T. Calman, F.R.S., and Professor J. Graham Kerr, F.R.S., for their advice and encouragement.

\section{Materials and Methods.}

The larvæ were observed both at the Marine Station at Millport and in the laboratory at Glasgow. It was found possible to transport larvæ to Glasgow ; their normal swimming activities did not appear to be upset by the laboratory conditions. Temperature seemed to be the most important environmental factor, and its careful control was necessary ; it was found that the condition of larvæ which had been adversely affected by a rise in temperature during the journey from Millport often improved remarkably after some hours in a more normal thermal environment.

After various methods had been tried it was found that the best way of maintaining an even temperature was to allow a constant stream of cold tap water to flow over the outside of the vessel containing the larvæ. The various jars and tubes in which the larvæ were observed were kept cooled in the same way.

The larvæ were watched in a variety of ways, the currents caused by the actions of the appendages being traced out with suspensions of 
carmine and indian ink. An attempt was made to test the efficiency of the swimming methods and for this purpose a jar $60 \mathrm{~cm}$. in height by $5 \mathrm{~cm}$. square was used. This jar had a centimetre scale attached to one side and the larvæ were timed by means of a stop-watch when making an excursion of $10 \mathrm{~cm}$. In every case the larvæ were allowed to start moving before the excursion was timed, and so they were given a "flying start."

In order to have some control over the movements of the larvæ the experiments were carried out in a darkened room and advantage was taken of the fact that the larvæ showed definite responses to the stimulus of light. The jar could be illuminated either from the top or from the bottom. It was anticipated that difficulties would arise with convection currents in the experimental jar, but they were found to be negligible. During the experiments no special precautions were taken to control the temperature. The dark-room was unheated and below ground level; its temperature varied little. The glass which was put between the light and the experimental jar was thick, and readings taken at the beginning and end of each experimental period showed that the heat generated by the light did not cause any appreciable rise in the temperature of the water in the jar.

During the experiments on orientation it was found necessary to study the behaviour of the larvæ in darkness. It was found that red light, such as is used for photographic purposes, has no apparent effect on the larvæ. They neither orientate nor swim in response to its presence. These experiments were carried out at Millport and the larvæ were observed by placing the vessel containing them in front of a window of ruby glass in the wall of the dark-room. This window gave light from an adjacent room so that control of the intensity of light falling on it was easy. In all cases the least intensity in which the orientation of the larvæ could be seen was used.

\section{The Swimming Methods of the Larve.}

In recording the swimming methods of the larvæ it is convenient to treat of one species in some detail and then to compare and contrast others with it. The type selected is the first larva of Munida bamffica, which was abundant in the plankton at Millport in the early spring.

\section{Munida bamffica, first larva.}

The larvæ of this species normally progress telson foremost. Motion is brought about by the action of the thoracic exopodites, which cause a stream of water to flow along the sides of the body, over the outside of the carapace and away past the head (Fig. 1). Reversal in the direction of movement was occasionally seen to be brought about by reversal in the 
direction of the effective beat of the thoracic exopodites, but this was never long continued. The more normal method of reversal, such as is brought into use when the larva collides with some object, is to bring the abdomen and telson slowly under the thorax; the body is then straightened again with a violent jerk, the result being that the animal is sent rapidly head forwards.

In addition to the current caused by the thoracic appendages there is also the respiratory current created by the second maxillæ. This

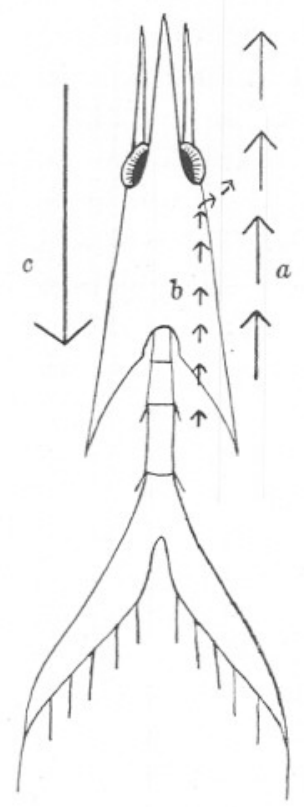

FIG. 1.-Munida bamffica (first larva). Diagram to show currents in water. Arrows represent: (a) current created by the thoracic exopodites, (b) respiratory current, (c) direction of movement.

latter current enters the branchial cavities from behind and, passing over the bases of the thoracic limbs, leaves the cavities behind the eyes; the eyes deflect the current outwards (Fig. 1).

In vertical movements swimming takes place either up or down according to the stimuli which excite the animal to make the excursion. Under experimental conditions it was found that at temperatures between $14^{\circ} \mathrm{C}$. and $20^{\circ} \mathrm{C}$. movement was towards the source of light. The change of direction of motion when the direction of the source of light was changed appeared almost instantaneous.

When they are not actively swimming the larvæ rest in a horizontal 
position, and the tendency to sink appears to be very slight. Figure 2 shows the positions of the larvæ during movement and at rest.

A study of the larva of Munida shows that (1) when swimming the body is orientated so that as little resistance as possible is offered to the water : this may be referred to as a "Stream-line effect" ; $(2)$ when resting the body is orientated so that the maximum resistance is offered to sinking; (3) that besides the normal swimming mechanism there is a well developed reversal mechanism.

\section{Caridea.}

Larvæ of Caridea were not plentiful in the material at my disposal, but two important types were observed, namely, Pandalus sp. and Crangon sp. The Pandalid larva swam towards the light telson foremost;
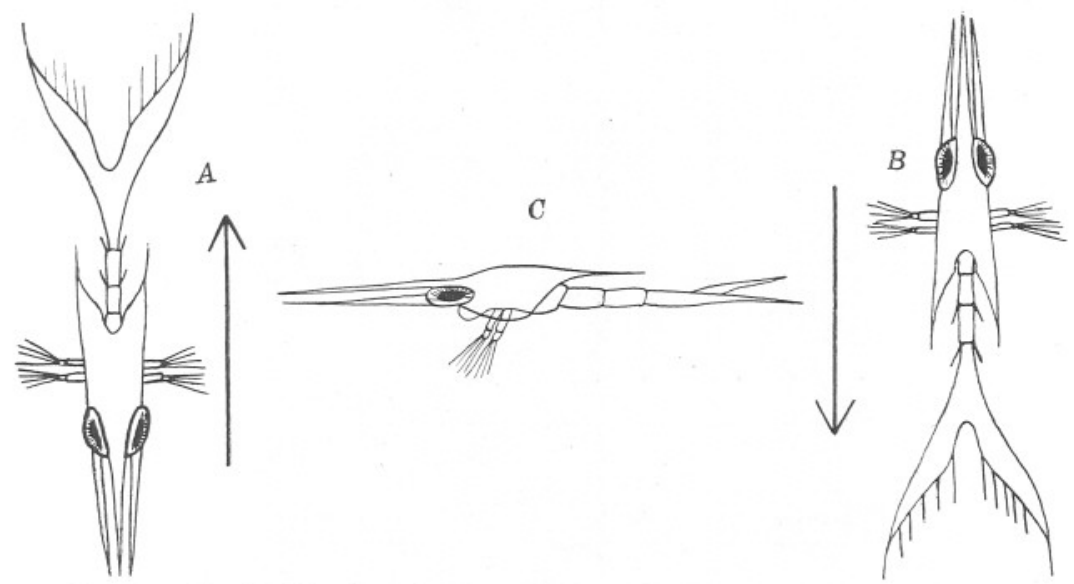

FIG. 2.-Munida bamffica (first larva). Diagrams to show orientation when swimming : $(A)$ upwards, $(B)$ downwards, $(C)$ when resting.

it swam and reversed in the same manner as a Munida larva. The backward swimming habit has also been noted in the Caridea by du Cane (1839) and by Lyon (1906), who observed it in Palomonetes varians; Lyon also suggested the manner in which the reversal mechanism would be found to work, but said that in this species the action was too quick to be followed by the eye.

The Crangonid larva swam head first. This is important as it shows that the habit of swimming telson foremost is not universal in the Caridea ; the significance of this will be discussed later.

Williamson (1901) has also noted that the larvæ of Crangon vulgaris progress head first; he also records a spiral movement as do du Cane (1839) and Weldon (1889). 


\section{Astacura.}

Several larvæ of Nephrops norvegicus were observed. In response to the stimulus of light they were found to orientate themselves with the telson and abdomen towards the light, but with the head and thorax in a plane at right angles to them, in the attitude shown in Figure 3. In this posture all the specimens moved towards the light telson first.

The swimming of the larvæ of Homarus vulgaris has been described by

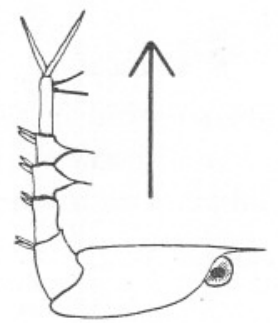

FIG. 3.-Nephrops norvegicus (larva). Diagram to show attitude when swimming; movement is in direction indicated by arrows.

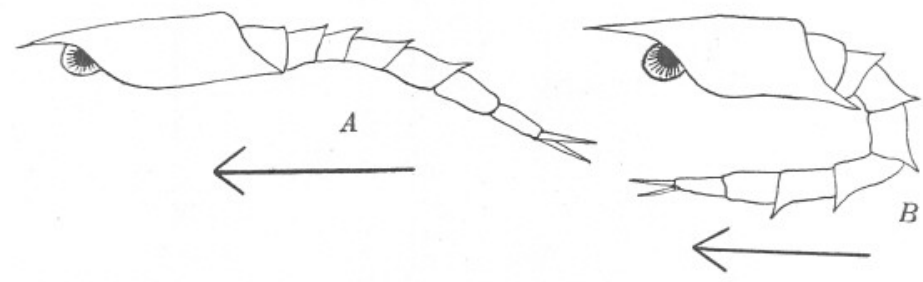

FIG. 4.-Homarus vulgaris (larva). Two attitudes seen when swimming. Movement takes place in the direction indicated by arrow.

Williamson (1904), who says that they swim with the abdomen downcurved, as in Figure 4A. They swim forwards. Occasionally he saw the abdomen curved under the body, Figure 4в.

\section{Anomura.}

In addition to the larvæ of Munida bamffica, larvæ of the following species were also observed : Galathea strigosa (first larva), G. dispersa (first larva), Eupagurus sp. (last larva), and Porcellana sp.

The swimming methods of the majority of these larvæ are essentially the same as those of Munida, but the case of Porcellana is somewhat different.

In Porcellana the larvæ normally progress head first. The long rostrum, however, tends to make them rather unwieldy creatures, and when the direction of stimulus is reversed the direction of the beat of 
the thoracic exopodites is reversed and the larvæ proceed backwards ; they do not rapidly re-orientate themselves as do the larvæ of other Anomurous types; that this is due to the presence of the long rostrum can be shown by cutting it off. When this is done the larvæ swim in the normal manner, but if the direction of the source of light is now reversed the larvæ rapidly re-orientate themselves to it.

The method of reversal in this species is the flexure of the abdomen and telson under the body; they are drawn sharply under the thorax and the larvæ jump backwards.

Spooner (1933) has also observed the swimming habits of certain Galatheid and Porcellana larvæ, and my observations appear on the whole to tally with his account.

The swimming of Anomurous larvæ has also been observed by Thompson (1903) who recorded the backward mode of progression.

\section{Jaxea sp.}

Thalassinidea.

A few specimens of this interesting larva were observed at Millport in September, 1933. In swimming they were found to be very like the Anomurous larvæ in habit, but unlike them they were very poor swimmers. However, they orientated themselves with the head away from the light and proceeded towards it telson foremost. The peculiar form of the body, which when flexed is divided into two almost equal portions, each of which presents a similar amount of surface to the water, results in the flexure and extension of the abdomen having no pronounced effect, and the writhing movements which take place move the larva very little, but tend to displace it slightly in the direction of the telson.

\section{Brachyura.}

Zoea larvæ of several species of Brachyura were observed; they responded positively to the stimulus of light. The positions adopted when swimming, both up and down, are shown in Figure 5; in both cases the larva is seen to be orientated so that it proceeds dorsal spine foremost. The swimming actions of the thoracic exopodites were occasionally seen to be supplemented by downward jerks of the telson region, but this was rare.

In contrast with the Anomurous larvæ the Brachyurous zoeas sink rapidly when the swimming movements cease, and a larva which appears to be swimming upwards may merely be lessening its tendency to sink. This is due to there being no position of rest ; these larvæ remain with the dorsal spine directed upwards, and unless the movements of the thoracic exopodites are continued the larvæ sink.

There is no really well-defined method of reversal, but in the event 
of a collision the telson and abdomen are violently agitated until the larva is clear of all obstruction.

The swimming habits of the Brachyurous zoea were studied by Weldon (1889), who came to the conclusion that the spines were of use to the larva in guiding its movements; the validity of this assumption will be discussed later.

Although the observations recorded above relate to one stage of the life-history only, namely that in which the thoracic appendages are
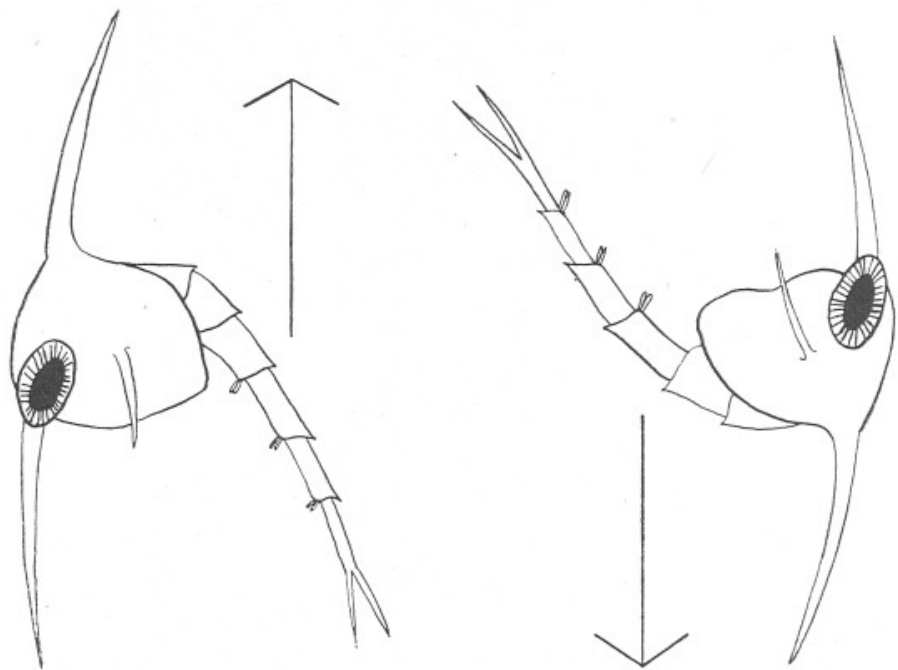

FIG. 5.-Diagram to illustrate the attitude of a Brachyurous zoea when swimming. Movement takes place in the direction indicated by arrows.

natatory, they will be sufficient to indicate the nature of some of the problems introduced by the study of the larvæ.

These problems may be conveniently divided into two groups :-

(1) The relation of the larva to its environment.

(2) The relation of the larva to other stages of the life-history.

The former presents physiological problems and the latter questions of morphology and phylogeny.

\section{The Relation of the Larva to its Environment.}

All larvæ have a tendency to sink. This tendency varies in (1) different species, (2) the same individual. As an example of the first it was found that at $19^{\circ} \mathrm{C}$. a larva of Porcellana sp. when narcotised sank at the rate of 1 metre in 350 secs., while a Brachyurous zoea of the Portunus type, under the same conditions, sank at the rate of 1 metre in 85 secs. In the 
same individual the tendency to sink will vary with several physical factors, for example viscosity. It will vary also with the orientation of the larvæ to gravity.

Munida bamffica larvæ give a very good example of variation in orientation with respect to movement. Figure 2 shows that when the larva is moving the minimum resistance is offered to the water, whereas while "resting" the maximum is offered. The case of the Brachyurous larvæ is entirely different. All the specimens studied were of the type found in Portunus, that is to say that all four spines of the carapace are present and fully developed. Here there is no position of rest as in Munida, but to prevent sinking the swimming movements have to be

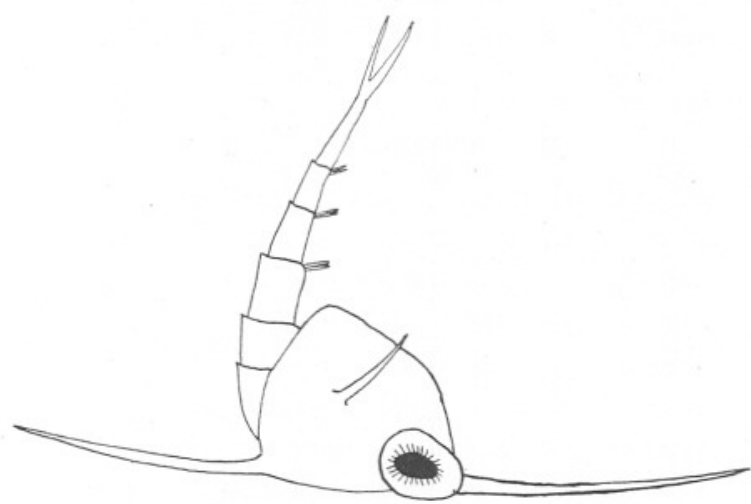

FIG. 6.-The attitude in which a narcotised Brachyurous zoea is found to sink.

continuous. The figure given above $(1 \mathrm{~m}$. in 85 secs.) for the sinking of a Brachyurous zoea is for a narcotised larva which sinks in the attitude shown in Figure 6. This attitude is never seen under normal conditions, where the dorsal spine is always directly upwards.

This question of orientation is best discussed under the two headings of orientation to (1) Light, (2) Gravity.

\section{(1) Orientation to Light.}

In the case of orientation to light we are concerned with larvæ in motion. Clarke (1932), working on Daphnia, came to the conclusion that here orientation is a phenomenon with a physiological basis different from that of the other phototactic responses. In the case of Palæmonetes, Lyon (1906) remarked that the larvæ as regards the mode of orientation are negatively phototropic, while in their movements they are positively phototropic; an idea which also indicates two distinct physiological 
processes. Spooner (1933) has shown that Decapod larvæ approach the source of light and not necessarily the point of greatest intensity of illumination.

This evidence suggests that certain areas of the eyes function as receptors which detect the direction of light, as appears to be the case in certain insects described by Mast (1924) and others.

Clarke (1930) pointed out that in Daphnia different responses were evoked by small and by large changes in the intensity of illumination ; these latter may be considered as shock stimuli. In the observations recorded in this paper shock stimuli were used, and in this case response to the direction of light is all important, the larvæ showing no response to gravity at all; they make excursions in any direction with any side directed downwards as recorded by Weldon (1889), Thompson (1903), and by Spooner (1933).

\section{(2) Orientation to Gravity.}

The fact that the stimulus of light completely overcomes that of gravity does not show that the latter does not exist, as Thompson appears to imply. When the stimulus of light is removed the larvæ cease to execute forced movements and are free to carry out random movements ; it is then that response to gravity is found.

Special attention has been paid to this aspect of orientation in Brachyurous zoea larvæ. In dull red light these larvæ appear to behave as if there were no light present at all. In these conditions they remain with the dorsal spine directed upwards and they carry out random movements in this attitude. The question arises as to how in the absence of light orientation is maintained. Gurney (1902) has pointed out that in the zoea stage there is no organ of balance and he suggested that the spines were in some way connected with this function. Experiments were undertaken with a view to investigating this.

It is clear from narcotising the larvæ that orientation is not a mechanical function of the body, but that it is dependent on consciousness. Amputation of the thoracic exopodites in a conscious larva also results in uncontrolled sinking, showing that orientation is also dependent on the muscular activity of these appendages.

Other functions of the spines which have been suggested are : (1) Protection; (2) Control of the direction of swimming; (3) Adaptation for resisting the tendency to sink.

These functions are not mutually exclusive, but one is probably primary, the others being secondary.

If these suggestions are examined more closely the following evidence is found. 


\section{(1) Protection.}

Gurney (1902) found that small fish such as Gobies had difficulty in swallowing Brachyurous zoeas on account of the spines; and I have to thank Mr. D. P. Wilson, of Plymouth, for informing me in a personal communication that he has seen Pipe-fish when feeding on a catch of mixed plankton deliberately pick out the copepods and avoid Brachyurous larvæ. When feeding the pipe-fish carefully scrutinise one organism after another and no attempt is made to get the zoeas into the mouth. While the cases are of great interest, it is difficult to suppose that small fish which exercise a choice are the chief enemies of zoeas; for in the autumn plankton hauls many Medusæ and Ctenophores were present, and many were found to contain Decapod larvæ. Also Williamson (1904) has recorded that the larvæ of Homarus vulgaris eat Cancer larvæ. It would not appear, therefore, that the chief function of the spines is protective.

\section{(2) Direction of Swimming.}

Weldon (1889) pointed out that the spines of many Crustacean larvæ show a great tendency to develop in one straight line, parallel to the axis of the body; he cites as examples the larvæ of Penæus and Hippolyte and the Galatheidea in general. And he said that the same result is arrived at in a slightly different way in the Brachyurous zoea. Perhaps it is not necessary to point out that this long axis of the body is in most cases the direction of movement. Weldon considered that the possession of these spines enabled the larvæ to make excursions more rapidly and in a more direct manner than larvæ which do not possess such spines. This must lead us to suppose that the spines have been developed to assist swimming movements in a definite direction. On the other hand, it must not be forgotten that if the spines were developed in connexion with some other function they would still control the direction of motion as movement in a plane at right-angles to that of the spines would be impossible for mechanical reasons.

I have to thank Dr. R. Gurney for pointing out that presumably Weldon is here referring to Claus's Hippolyte which has since been shewn to be Callianassa.

With regard to excursions in direct lines, experiments have shown that if the spines are cut off the larvæ lose none of their powers of swimming in a straight line nor are their swimming abilities in any way upset. It seems more probable that these larvæ owe their powers of direct and rapid movement to the very highly developed swimming mechanism which they possess, assisted, as Gurney's hypothesis would appear to indicate, by an efficient sensory organ functioning as does an otocyst and so helping the larva to maintain a definite orientation. 
(3) Adaptations for resisting the tendency to sink.

In larvæ such as those of Munida, where a position of rest is taken up, there can be little doubt that the spines help to maintain the animal in a constant position in the water, but in the Brachyurous zoea no such position is known. That is to say, that the large dorsal and rostral spines are never in such a position as to aid flotation. In the case of the narcotised larva, however, these spines immediately come into the horizontal plane; here their effectiveness as adaptations against sinking is shown by the following examples:

(1) Zoea 1.

Temp. $17 \cdot 4^{\circ} \mathrm{C}$.

Normal zoea.

Average sinking time for 6 journeys of $10 \mathrm{~cm}$.

$83 \cdot 4$ sec. per $1 \mathrm{~m}$.

Same zoea.

Dorsal spine cut off. Average sinking time for 6 journeys of $10 \mathrm{~cm}$.

$66 \cdot 0$ sec. per $1 \mathrm{~m}$.

Same zoea.

Rostral spine also cut off. Average sinking time for 6 journeys of $10 \mathrm{~cm}$.

$64 \cdot 4$ sec. per $1 \mathrm{~m}$.

(2) Zoea 2.

Temp. $19^{\circ} \mathrm{C}$.

Normal zoea.

Average sinking time for 6 journeys of $10 \mathrm{~cm}$.

$130 \cdot 6$ sec. per $1 \mathrm{~m}$.

Same zoea.

Dorsal and rostral spines cut off. Average

sinking time for 6 journeys of $10 \mathrm{~cm}, \quad$. $121 \mathrm{sec}$. per $1 \mathrm{~m}$.

There is, however, one period when this position seen in the narcotised larva is taken up during life, and that is during the periods of the moults when the larva has no control over its actions. Any adaptations which would lessen the tendency to sink while the moult is taking place would be an advantage, for the next stage larva would then have a lesser distance to swim up in order to regain its normal position in the plankton.

It may be pointed out that in the Megalopa stage the spines, if present, are small, and during its moult the larva must sink rapidly, so that the young crab stage automatically takes up its position at a greater depth. This point is of interest as Dr. Lebour (1928a) has pointed out that at least in British species there is only one megalopa stage. 


\section{(4) Organs of Orientation.}

The suggestion made by Gurney (1902) that the spines in some way help the larva to orientate never appears to have had much attention devoted to it. Experiments and observations were made on living larvæ with a view to seeing if any facts could be brought to light which would strengthen or confirm Gurney's hypothesis. For the purpose of these experiments larvæ taken in the plankton were used; they were referred to the genera Portunus and Cancer. In the experiments which involved amputation of spines various control methods were devised, and it was shown that the phenomena observed were due to the injuries to the spines and not to the antennæ.

Observations on living larvæ which are not making excursions show definitely that orientation to gravity exists. The behaviour of a normal larva in dull red light has already been described; if the spines of such a larva are cut off either under an anæsthetic or not the behaviour, while remaining normal in the presence of white light, in the red light immediately becomes remarkably different. All sense of direction is lost; a larva that ceases to swim sinks in an uncontrolled manner, and larvæ which continue to swim pursue a spiral course and eventually finish with a spiral dive to the bottom of the containing vessel ; once they have reached the bottom they find it very difficult to leave it again. In short, a larva which has had the spines cut off, although it behaves normally in light, in darkness cannot find its way about. The observations recorded above show that Gurney's suggestion is worthy of consideration.

How such an orientation mechanism would work is not easy to see at first glance, but the spines may probably be of assistance in magnifying differential pressure on the sides of the body. It may be noted that the spines appear to be very sensitive to touch, and if any of the four spines are touched with a needle or held with a pair of forceps, the telson is immediately bent round and scrapes the spine as if trying to remove the foreign object, in the same way that Gurney has described it cleaning the dorsal spine (1902).

In this connexion Dr. Lebour (1928b) has pointed out that the larvæ of Ebalia tuberosa have only rudimentary spines on the carapace and has suggested that this, together with the peculiar form of the telson, the fork of which is nearly obliterated, may be correlated with their bottomliving habit. Dr. Lebour goes on to point out that the larvæ of Pinnotheres pisum, another bottom-living species, show somewhat the same characters, but that the closely related $P$. veterum has all the spines of the carapace normally developed and has also a much larger telson in keeping with the fact that it is not restricted to the lower layers of the water, but is found right up to the surface. 
In the absence of further evidence it is impossible to say whether the restriction of these species to the lower layers is due to their tendency to sink having no mechanical check, or whether it is due to these animals failing to find their way about during the hours of darkness.

\section{Speed of Swimming.}

Little appears to be known of the swimming capabilities of Crustacean larvæ; Steuer (1910) records that a small Decapod larva could maintain its position against a current of water moving at the rate of 1 metre in 40 sec. The following are some average figures for specimens timed in the manner described above :-

Galathea strigosa (first larva). . . Up at the rate of $1 \mathrm{~m}$. in 50 secs. , , , , . . Down ,, ,, 45 ,, Galathea dispersa (first larva). . . Up at the rate of $1 \mathrm{~m}$. in 56 secs. , , , , . . Down , . , 50 ,,

Eupagurus sp. (last larva). . . Up at the rate of $1 \mathrm{~m}$. in 50 secs. , " , , . . Down ,, , 60 ,

The above results were obtained at a temperature of $16^{\circ} \mathrm{C}$. approx.

Pandalus sp. (late larva) at $17^{\circ} \mathrm{C}$. . Up at the rate of $1 \mathrm{~m}$. in 67 secs. ", , , . Down , , 48 ,

Porcellana sp. at $17^{\circ} \mathrm{C}$.

When moving head first.

$\mathrm{Up}$ at the rate of $1 \mathrm{~m}$. in 65 secs.

When moving telson first. . . Up at the rate of $1 \mathrm{~m}$. in 92 secs. Down ,, , 78 ,,

There are one or two remarks to be made about these figures. Firstly, they do not pretend to be very precise, but are included here as they show a rather remarkable similarity in different species and also approach the figure quoted above from Steuer. Secondly, the effect of gravity in the downward movement is not very noticeable in the smaller larvæ, such as the Anomurous forms, but in some of the larger species has a noticeable effect, for example in Pandalus. Thirdly, it will be seen that the speed of swimming in Porcellana larvæ depends on orientation.

In any attempt to apply these figures to conditions in the sea two uninvestigated factors have to be borne in mind : (1) Fatigue, we do not know how long the larvæ can keep up the speeds found in the experiments. (2) We do not know if the excursions made in the sea are really vertical and as direct as those made in response to an artificial stimulus.

If, however, the experimental conditions are in any way comparable to those found in nature, a migration of 40 metres could be carried out by 
a Porcellana larva, for instance, in about 40 minutes. This is well within the time given by Russell (1928), who has recorded such a migration taking place within two hours.

From the observations recorded above it is clear that the swimming activities of the larvæ are sufficient to account for the migrations which actually take place in the sea, and there is no need to invoke the aid of physical factors as do the theories of Ostwald and others. As regards the downward movement, it has been suggested that this is not due to the activities of the larvæ, but due to the injurious effect of the light inhibiting their movements so that they sink into deeper water where in the more congenial surroundings they become normally active once again. In my opinion the following facts: (1) that given a suitable stimulus the larvæ swim downwards; (2) that if the larvæ lose their power of movement they become orientated so as to afford increased resistance to the tendency to sink: show that as far as Decapod larvæ are concerned the downward movement is not a passive one, but an active one. Were the inhibition hypothesis correct, one would expect that the process of natural selection would have acted so that on loss of power of orientation the sinking to lower layers of water would have been as rapid as possible.

Finally, a practical point arises: should the vertical migrations in the sea take place at a rate in any way comparable with that found in the laboratory, the validity of conclusions as to the composition of populations as ascertained by horizontal hauls taken over any considerable length of time is brought into question. The experimental evidence leads me to suppose that marked changes in distribution may take place in such a short time as 15 minutes. This may serve to emphasise, if emphasis be needed, the importance of the time factor which has been fully discussed by Russell (1928).

\section{The Relation of the Larva to the other Stages of the LIFE-HISTORY.}

Under this heading several points of morphological interest will be discussed. The larva may be looked upon as a free-living young stage well adapted to its mode of life; it comes between the stage passed through in the egg and the adult. During the larval stages swimming is one of the most important functions and it is not unnatural to assume that many of the structural modifications seen are connected with it. In the next few paragraphs an attempt will be made to indicate how the mode of swimming is influenced by the degree of development reached on hatching from the egg, and how, in turn, the mode of swimming influences the transition of the larva into the adult.

The nauplius is best regarded as a precociously developed head 
(Graham Kerr, 1921) and it may be assumed that in an ideal larva the remaining segments of the body would develop in succession, each bearing a pair of appendages. The appendages of the nauplius do not, however, develop in their final form, but are temporarily modified to serve both swimming and feeding functions. When the later appendages appear they take over these duties, allowing the naupliar appendages to be remodelled and to assume the functions which they serve in the adult. In this way the swimming function would be passed backwards firstly to the thoracic and finally to the abdominal appendages.

It is interesting to note that this condition is nearest approached in the Penæidea where the swimming function is passed from head to thorax and then in turn to the abdomen; but even here a modification, typical of the Eucarida, is to be noted; this is that the segments of the hinder part of the body develop long before the appendages, and that the posterior thoracic region is compressed ; this leads on to the condition seen in other groups of the Eucarida, for example, the Caridea, where the segments of the posterior thoracic region are not differentiated until the greater part of the abdomen is developed. From the observations recorded above it would appear very likely that these modifications are due to the early need of the reversal mechanism which all these larvæ possess; also it is for the same reason that the uropods, which form a part of the mechanism, are precociously developed in many species.

The Euphausid type of development is often quoted as being primitive, owing to the very large number of stages passed through; but the very late appearance of the thoracic appendages would appear to point to a modification of the condition found in the Penæidea, the naupliar mode of progression being retained to a very late stage.

It should be noted that the various accounts of Euphausid larvæ are not very conclusive as to the swimming methods of these animals. From the evidence of Lebour (1925, p. 811) it would seem that the antennæ are the swimming organs until the end of the Furcilia stages is reached. It is during the Cyrtopia stages that the antennæ become differentiated into their adult constituents, and as Dr. Lebour goes on to say that the Cyrtopia merges imperceptibly into the adult one gathers that during these stages the pleopods are carrying out the function which they serve in the adult, namely, swimming. Cannon and Manton (1927), on the other hand, state (p. 247) : “. . . many larval forms, such as Euphausid larvæ, can walk on the endopodites of their thoracic limbs while the exopodites are swimming organs." They do not indicate at what stage the larvæ are observed to swim with the thoracic exopodites; from Dr. Lebour's careful account it would not appear that this can be seen before the end of the Furcilia stages. Dr. Lebour, as is noted above, also 
says that the change from Cyrtopia to adult is imperceptible, so it is unlikely that any great change of function takes place here, and, as I have already said, the account given by Dr. Lebour leads me to suppose that during the Cyrtopia stages the appendages are carrying out the same functions which they serve in the adult. The functions of the appendages of the adult Euphausid have been described by Manton (1928), who says (p. 107 et seq.) that the pleopods are swimming organs, the thoracic exopodites being mainly concerned in producing a respiratory current. In my own limited observations all the Euphausid larvæ which I saw swam with the antennæ until the pleopods were developed.

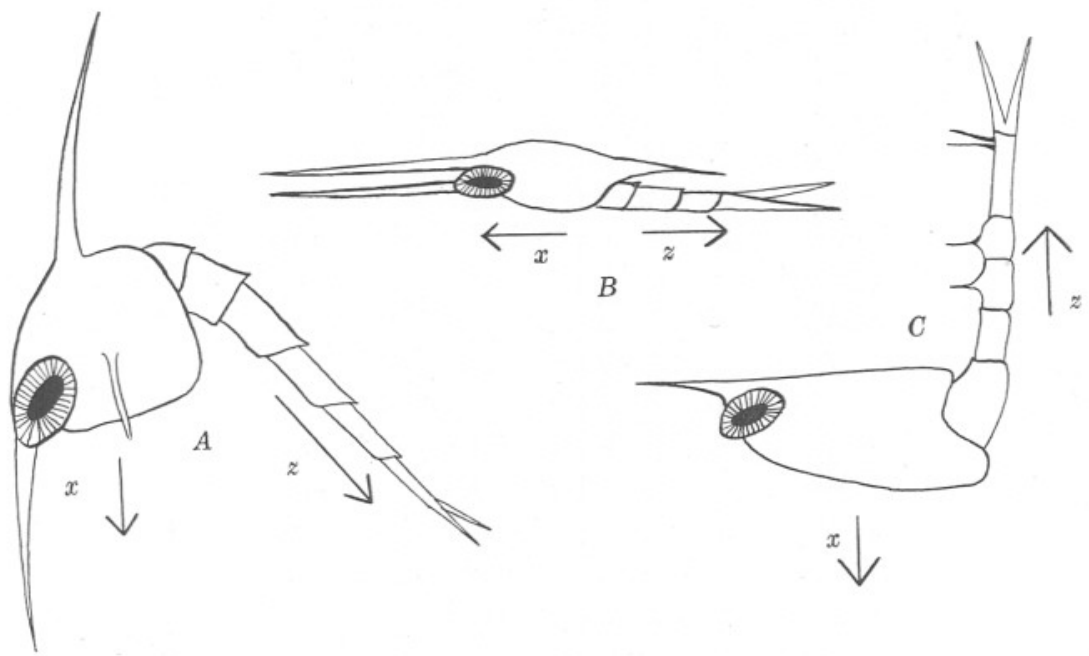

Fig. 7.-(A) Brachyurous zoea, $(B)$ Munida bamffica (first larva), (C) Nephrops norvegicus larva (not to same scale). Diagram to show the direction of the effective beat of the thoracic exopodites, indicated by arrow $x$, and the direction in which the pleopods would beat if they were functional, indicated by arrow $z$.

In the Caridea although the development of the appendages is delayed, their order of appearance is from front to back, the thoracic exopodites becoming functional in sequence, except that of the fifth pereiopod which is never used for swimming. The Caridea have no naupliar stages so that no direction of movement is imposed upon the mysis stage as it would be if the antennæ were natatory as in the Penæidea. It is this absence of control which has probably resulted in the backward movement found in so many members of this and other groups. In the absence of any foreordained direction of movement the larvæ have been free to move in any direction and it is logical to assume that the backward one has been favoured, as with motion taking place in this direction the respiratory current would assist the movement and not hinder it. Not all larvæ, 
however, have adopted this method of progression; Crangon is an example of this : here the rotatory movement which has been recorded is probably not due to the absence of spines, as Weldon (1889) supposed, but to a relatively slow rate of movement, as compared with Portunus and Munida larvæ, caused by the antagonistic effect of the respiratory current.

The backward movement has undoubtedly contributed largely to the functional discontinuity between the mysis stage and that stage in which the pleopods first become functional. This discontinuity may also be due, in a large degree, to the postures taken up by different larvæ in which the abdomen is held in such an attitude that any action on the part of the pleopods would result in movement in a different direction to that caused by the action of the thoracic exopodites (see Figure 7).

The difference in the direction of the effective beat of the thoracic and abdominal appendages has been a dominating feature of the evolution of the larval forms of the Decapoda. As a result the natatory function has been confined to the more anterior thoracic exopodites which in such types as the Brachyurous zoea are highly specialised for this purpose.

It is disappointing that there are no records available of the swimming habits of the later larvæ of the Penæidea.* In such a species as Penaopsis stebbingi, the development of which has been described by Gurney (1927), it is difficult to imagine any abrupt change in swimming habits between the naupliar and mysis stages, the development of the thoracic appendages being very gradual; there is, however, a rather abrupt change to the Mastigopus stage. A form in which this latter change appears to be less marked is that of Acetes recorded by Brooks (1882). The functional significance of this discontinuity in the Penæidea is at present unknown, but occurring in this series of larvæ it is interesting as there is no apparent reason why the change from mysis to mastigopus should not be as gradual as that from nauplius to mysis. The explanation may lie in a difference of posture of thorax and abdomen such as has been described in other larvæ.

\section{SUMMARY.}

The swimming methods and habits of certain Decapod larvæ have been observed. The first larva of Munida bamffica was chosen for special attention. Such a study shows the importance of (1) orientation, (2) the presence of a reversal mechanism.

Observations on other types show these factors to be of great import-

* Gurney (Ann. Mag. Nat. Hist. Ser. 9, Vol. 18, 1926, p. 26) has dealt with the swımming methods of Penæid larvæ in general terms . but apart from Müller's observations there quoted we have no records of the attitudes in which these larvæ swim. especially in response to external stimuli. 
ance and also show that there are a great variety of attitudes in which larvæ swim.

Points in the relation of the larvæ to their environment were next considered; orientation is again important here, but whereas in Munida larvæ a "resting" orientation is found no such attitude is seen in Brachyurous zoeas.

Orientation to light was found to overpower completely orientation to gravity, but orientation to gravity exists, and it is argued that Gurney's hypothesis, which connects the spines of the carapace with the maintenance of equilibrium, should be examined more closely.

It is suggested that in the Brachyurous zoea the spines are of use as adaptations for lessening the tendency to sink mainly during the periods of moulting.

The speed of swimming has been considered and it is found that at temperatures of $14^{\circ}$ C. $-18^{\circ}$ C. Anomurous larvæ can travel at the rate of 1 metre in 1 minute. This is a time well in accordance with Russell's results, obtained in the English Channel. Here fatigue is an unknown factor and it is not known if the whole migration is carried out in one stage ; if it were a migration of 40 metres such as Russell records it might take place in 40 minutes.

Reasons are given for believing that the downward migration of larvæ found at dawn is due to the activities of the animals themselves and not to physical factors or to passive sinking due to inhibition of movement resulting from an injurious effect of light.

The origin of some of the structural adaptations of the larvæ is discussed. The precocious development of the posterior region of the body is considered to be due to the early need for a reversal mechanism, provided for by the caudal fan at the end of a flexible abdomen. The importance of posture when swimming is pointed out and it is maintained that the backward movement seen in so many larvæ has helped to emphasise the metamorphosis between the last mysis stage and that in which the pleopods first become functional.

The backward movement itself is considered to be due to the absence of a naupliar stage in the life-history ; thus the mysis has no foreordained direction of movement and so in many cases swims backwards in order that the respiratory current will aid rather than hinder the speed of movement.

The swimming habits of crustacean larvæ and their bodily form are thus seen to be closely related. 


\section{LIST OF REFERENCES.}

Brooks, W. K. 1882. Lucifer: A Study in Morphology. Philos. Trans., 173 , pp. 57-137, pls. i-xi.

Cannon, H. G., and Manton, S. M. 1927. On the Feeding Mechanism of a Mysid Crustacean, Hemimysis Lamornæ. Trans. Roy. Soc. Edinb., 55, pt. 1, No. 10, pp. 219-253, pls. i-iv, text-figs. 1-16.

Clarke, G. L. 1930. Change of Phototropic signs in Daphnia induced by Changes of Light Intensity, J. Exp. Biol., 7, pp. 110-131, textfigs. $1-8$.

1932. Quantitative aspects of the change of Phototropic sign in Daphnia. J. Exp. Biol., 9, pp. 180-211, text-figs. 1-11.

du Cane, C. 1839. Metamorphosis of Crustacea. Ann. Nat. Hist., 2, pp. 178-181, pls. vi-vii.

Gurney, R. 1902. The Metamorphosis of Corystes cassivelaunus (Pennant). Quart. J. Micr. Sci., N.S., 46, pp. 461-478, pls. xxix-xxxi.

1927. Zool. Results of the Cambridge Exp. to the Suez Canal, 1924. XV Rept. on Larvæ of the Crustacea Decapoda. Trans. Zool. Soc. Lond., 22, pt. 2, pp. 231-286, text-figs. 49-76

Kerr, J. Graham. 1921. Zoology for Medical Students, pp. 1-485+x, text-figs. 199. London, 1921.

Lebour, M. V. 1925. The Euphausiidæ in the Neighbourhood of Plymouth. II. Nyctiphanes Couchii and Meganyctiphanes norvegica. J. Mar. Biol. Ass. U.K., N.S., 13, pp. 810-847, pls. i-ix.

1928a. The Larval Stages of the Plymouth Brachyura. Proc. Zool Soc. Lond., 1928, pt. 2, pp. 473-560, pls. i-xvi, text-figs. 1-5.

1928b. Studies of the Plymouth Brachyura. II. The Larval Stages of Ebalia and Pinnotheres. J. Mar. Biol. Ass. U.K., N.S., 15, No. 1, pp. 109-118, pls. i-ii, text-fig. 1.

Lyon, E. P. 1906. Note on the Heliotropism of Palæmonetes Larvæ. Biol. Bull., 12, pp. 23-25.

Manton, S. M. 1928. On Some Points in the Anatomy and Habits of the Lophogastrid Crustacea. Trans. Roy. Soc. Edinb., 56, pt. 1, No. 5, pp. 103-119, pls. i-iii, text-figs. 1-2.

Mast, S. O. 1924. The Process of Photic Orientation in the "Robber Fly " Proctacanthus philadelphicus. Amer. J. Physiol, 68, pp. 262279 , text-figs. $1-5$. 
Russell, F. S. 1928. The Vertical Distribution of Marine Macroplankton. VI. Further Observations on Diurnal Changes. J. Mar. Biol. Ass. U.K., N.S., 15, pp. 81-104, text-figs. 1-7.

Spooner, G. M. 1933. Observations on the Reactions of Marine Plankton to Light. J. Mar. Biol. Ass. U.K., N.S., 19, pp. 385-438, textfigs. 1-22.

Steuer, A. 1910. Planktonkunde, pp. $723+x v$, text-figs. 365, pl. i. Leipzig, 1910,

Thompson, M. T. 1903. The Metamorphoses of Hermit Crabs. Proc. Boston N.H. Soc., 31, No. 4, pp. 147-209, pls. iv-x.

Weldon, W. F. R. 1889. Notes on the Function of the Spines of the Crustacean Zoœa. J. Mar. Biol. Ass. U.K., N.S., 1, pp. 169-170, pl. i.

Williamson, H. C. 1901. On the Larval Stages of the Decapod Crustacea. The Shrimp (Crangon vulgaris, Fabr.). Rept. Fish. B. Scot., XIX, pt. iii, pp. 92-119, pls. i-vi.

— 1904. A Contribution to the Life-History of the Lobster (Homarus vulgaris). Rept. Fish. B. Scot., XXIII, pt. iii. pp. 65-107, pls. i-iv. 



\title{
The Biology of Balanus balanoides. I. Growth rate and its relation to Size, Season and Tidal Level.
}

\author{
By \\ Hilary B. Moore, Ph.D., \\ Zoologist at the Marine Biological Station, Port Erin, Isle of Man.
}

With 4 Figures in the Text.

THREE workers have contributed recently to our knowledge of the growth rate of Balanus balanoides : Runnström (1925), and Hatton and FischerPiette (1932). The former kept a single patch of barnacles under observation for a year at Herdla, which is about $27 \mathrm{~km}$. north-west of Bergen. By estimating at different times of year the size distribution of the spat, and of the first and second year groups, which he could differentiate by their size, colour and shape, he obtained a curve for the growth of the animal for the normal duration of its life. His investigations also cover the maturation of the gonads. And he finds that the normal course of life is for the animals to settle on the rocks in April. Towards the end of the following year the ovaries are developed, and in the spring of the third year the larvæ are liberated. Most of the adults die after this, only a possible few surviving to spawn the following spring. His measurements comprise the length only of the shells, and he says that the successive year groups may be distinguished by their degree of flattening.

Hatton and Fischer-Piette (1932) worked on the growth of individuals near St. Malo during the greater part of two years, and investigated the effects of varying degrees of shelter and tidal level on this growth rate. Their results will be referred to in greater detail later in this paper, but they may be summarised in the following two relations: the most larvæ settle, and the greatest growth takes place, at the most exposed places, and at the lowest tidal levels. They show also that growth is at a maximum from April to June-July, and practically at a standstill for the rest of the year.

\section{Methods.}

In the present work it was felt that it would be desirable to employ a method of measurement which would allow of the calculation of the volume of the animal. This is necessary in the first place to cope with the variations of shape as between individuals, and in the second place to afford a measure which, unlike length, increases more or less in a simple 